\title{
Effect of Boron and Cross-Section Thickness on Microstructure and Mechanical Properties of Ductile Iron
}

\author{
Keivan A. Kasvayee ${ }^{1, a^{*}}$, Matteo Ciavatta ${ }^{2, b}$, Ehsan Ghassemali ${ }^{1, c}$, \\ Ingvar L. Svensson ${ }^{1, \mathrm{~d}}$, Anders E. W. Jarfors ${ }^{1, \mathrm{e}}$ \\ ${ }^{1}$ School of Engineering, Jönköping University, Box 1026, 55111 Jönköping, Sweden \\ ${ }^{2}$ University of Bologna, Via Zamboni, 33, 40126 Bologna, Italy \\ aKeivan.Amiri-Kasvayee@ju.se, ${ }^{b}$ matteo.ciavatta@studio.unibo.it, 'Ehsan.Ghassemali@ju.se, \\ Ingvar.Svensson@ju.se, ${ }^{\mathrm{e} A n d e r s . J a r f o r s @ j u . s e ~}$
}

Keywords: Spherical graphite iron, boron, ductile iron, mechanical properties, component casting, hardness

\begin{abstract}
Effect of boron contamination on the microstructure and mechanical properties of ductile iron, GJS-500-7 grade was studied. Three cast batches with the boron content of 10, 49 and $131 \mathrm{ppm}$ were cast in a casting geometry containing plates with thicknesses of 7, 15, 30, 50 and $75 \mathrm{~mm}$. Microstructure analysis, tensile test, and hardness test were performed on the samples which were machined from the cast plates. Addition of $49 \mathrm{ppm}$ boron decreased pearlite fraction by an average of $34 \pm 6 \%$ in all the cast plates. However, minor changes were observed in the pearlite fraction by increasing boron from 49 to $131 \mathrm{ppm}$. Variation in the plate thickness did not affect the pearlite fraction. The $0.2 \%$ offset yield and ultimate tensile strength was decreased by an average of $11 \pm 1 \%$ and $18 \pm 2 \%$, respectively. Addition of $49 \mathrm{ppm}$ boron decreased Brinell hardness by $16 \pm 1 \%$, while $11 \pm 2 \%$ reduction was obtained by addition of $131 \mathrm{ppm}$ boron.
\end{abstract}

\section{Introduction}

During the past decades, the amount of boron build-up in the iron scrap feeds has been increased. Many foundries have reported that they have problems with the tramp levels of boron contamination which cause lower hardness in cast components which were produced from pearlitic ductile iron, thus requiring excess pearlite promoting alloy elements to satisfy the quality control [1, 2]. This could cause additional costs to the foundries both relating to the cost of the consumables and re-manufacturing of the components. Thus, investigating the effect of boron on the microstructure and mechanical properties of the components is essential to improve the quality and reduce the costs of production.

It is well known that boron as an alloying element can improve the hardenability of steels [3]. However, the presence of small amounts of this element (even in trace level) in cast irons can affect the microstructure and mechanical properties. This effect can be advantageous or deleterious, for example increase in wear resistance [4] or decrease in hardness [5], subsequently. Boron does not fade from the melt during re-melting [1]. Boron contamination in the melt can increase ferrite fraction [6] and/or produce carbides in the microstructure of cast iron [7, 8]. Boron sources are normally in the scarps that are used in the furnace charge such as: tool steels, interstitial-free steels, hardenable steels, malleable iron, enameled scraps (e.g. cast iron baths, cooker handles and sause pans), silicon carbide charge materials and certain furnace lining materials $[5,6,9]$, as well as machining chips, which are contaminated with machining lubricant.

In ductile iron, boron increases the carbon equivalent, which can increase precipitated graphite and decrease dissolved carbon content in the matrix [10]. Boron contents higher than 5 ppm can have deleterious effect on production of as cast fully pearlitic ductile iron [9]. Carbides initiate in contents higher than $20 \mathrm{ppm}[5,11]$. Boron levels ranging from less than $5 \mathrm{ppm}$ up to $26 \mathrm{ppm}$ can increase the ferrite fraction from $6 \%$ to as high as $43 \%$ [2]. By increasing the boron content to $80 \mathrm{pm}$ filamentary carbides possibly form in the cell boundaries [11]. Boron amounts higher than $200 \mathrm{ppm}$ was reported to increase the nodule count and consequently decrease the size of nodules in 
ferritic ductile iron [12]. Moreover, graphite nodularity was deteriorated by increasing the boron content $[10,13]$.

In pearlitic ductile iron, higher amounts of boron contamination can deteriorate hardness, ultimate tensile strength, and yield strength due to the increase in ferrite fraction and deterioration of the nodularity [10]. Addition of pearlite stabilizing elements such as nitrogen (N), titanium (Ti), manganese $(\mathrm{Mn})$, cupper $(\mathrm{Cu})$ and tin $(\mathrm{Sn})$ were used to contradict these effects, and return the standard hardness and strength of ductile iron $[1,14]$. In addition, it has been reported that $\mathrm{Na}_{2} \mathrm{CO}_{3}$ is efficient to remove boron from iron melt [15]. However, in ferritic ductile iron, boron levels up to $200 \mathrm{ppm}$ did not reveal any deleterious effect on the mechanical properties of ductile iron pipes with ferritic microstructure, while higher than this level decreased the toughness of the pipes because of higher amount of pearlite and carbide formed in the microstructure [12].

This study focuses on the effects of boron content and section thickness on the microstructure and mechanical properties of ductile iron grade GJS-500-7. To determine these effects, boron content and section thickness were the factors that were varied. Microstructural investigation as well as mechanical testing were performed on the cast material. The results were compared with respect to plate thickness and boron content.

\section{Experimental}

Three batches of ductile iron grade GJS-500-7 were cast with three different levels of boron content of 10, 49, and $131 \mathrm{ppm}$. The composition of the cast material is presented in Table 1 . Chemical analysis was performed on the white solidified coin shaped samples, which were cast from the melt, using spark spectrometry analysis.

Table 1. Chemical composition of the cast material.

\begin{tabular}{|l|c|c|c|c|c|c|c|c|c|c|c|c|c|}
\cline { 2 - 14 } \multicolumn{1}{c|}{} & \multicolumn{10}{c|}{ Element (Wt.\%) } & \\
\hline $\begin{array}{l}\text { Cast } \\
\text { batch }\end{array}$ & $\mathbf{C}$ & $\mathbf{S i}$ & $\mathbf{M g}$ & $\mathbf{P}$ & $\mathbf{S}$ & $\mathbf{B}$ & $\mathbf{C r}$ & $\mathbf{N}$ & $\mathbf{C u}$ & $\mathbf{M n}$ & $\mathbf{S n}$ & $\mathbf{T i}$ & $\mathbf{C}_{\text {eq }}$ \\
\hline $\mathbf{1}$ & 3.4 & 2.3 & 0.046 & 0.03 & 0.008 & $\mathbf{0 . 0 0 1 0}$ & 0.05 & 0.06 & 0.35 & 0.41 & $<0.01$ & 0.01 & 4.27 \\
\hline $\mathbf{2}$ & 3.4 & 2.3 & 0.039 & 0.03 & 0.005 & $\mathbf{0 . 0 0 4 9}$ & 0.05 & 0.02 & 0.34 & 0.41 & $<0.01$ & 0.01 & 4.28 \\
\hline $\mathbf{3}$ & 3.5 & 2.3 & 0.043 & 0.03 & 0.008 & $\mathbf{0 . 0 1 3 1}$ & 0.05 & 0.03 & 0.35 & 0.41 & $<0.01$ & 0.01 & 4.26 \\
\hline
\end{tabular}

The casting geometry is schematically shown in Figure 1. It contained six different cast plates with thicknesses of $3,7,15,30,50$, and $75 \mathrm{~mm}[16,17]$. The total weight of each batch was $105 \pm 5 \mathrm{~kg}$. Casting was performed in industrial scale in Arvika Gjuteri AB, Sweden. However, the $3 \mathrm{~mm}$ plates did not completely fill in any of the trials, thus, they were excluded from the study.

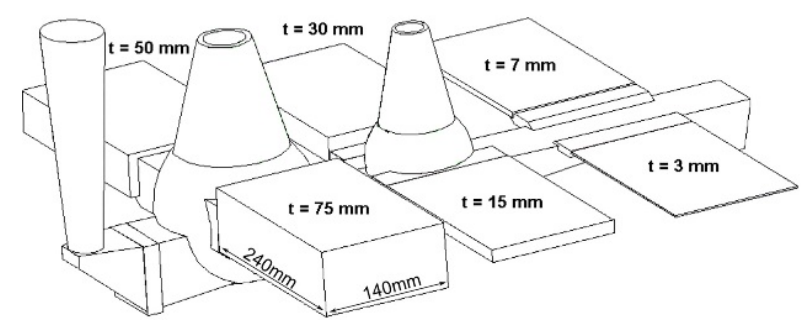

Figure 1. Casting geometry, containing six plates with different thicknesses.

The melt temperature was $1400{ }^{\circ} \mathrm{C}$. The $\mathrm{Mg}$ treatment was performed via the Tundish cover method [18]. The pouring temperature was $1270 \pm 10^{\circ} \mathrm{C}$. Inoculation was performed in stream using Foundrisil particles $(0.2-0.7 \mathrm{~mm})$. Sampling was done by coins. The molds were produced using Furan sand. Ferro-boron particles were added to the melt in $500 \mathrm{~kg}$ ladle prior to casting. The boron content in ferro-boron was $18 \%$, and a yield of $75 \%$ was considered when it was added to the melt. The total weight of each casting was $105 \pm 5 \mathrm{~kg}$. Note that cast 1 is considered as the reference material as it was used by the foundry for component casting. 
Three tensile samples were produced and tested from middle layer of each plate (in total 45 tensile samples). Microstructural analysis and hardness tests were performed on three samples from each plate, which were located in vicinity of each tensile sample. The positions of tensile, hardness and microstructure analysis samples in a typical cast plate are schematically shown in Figure 2 . The results that represented each plate were obtained from an average of the results of these samples.

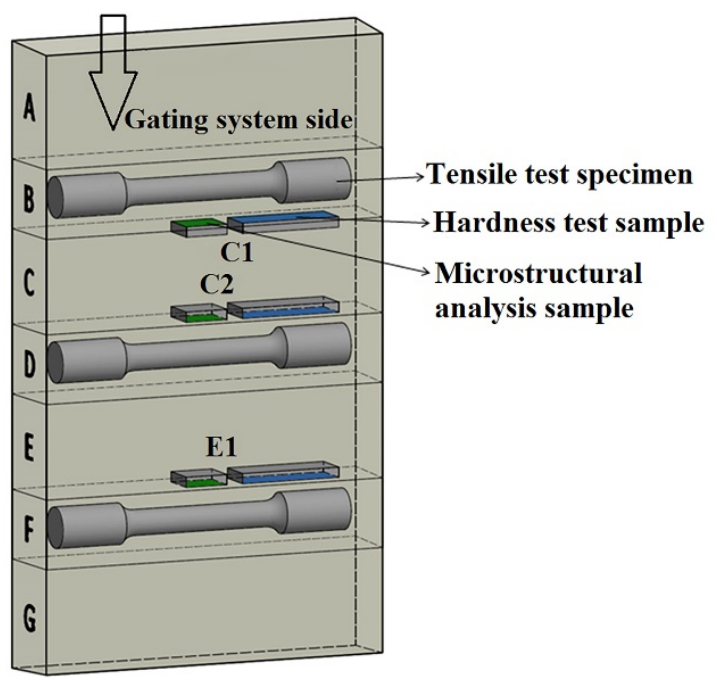

Figure 2. Schematic illustration of a typical cast plate showing the position of the tensile, hardness and microstructural analysis samples.

Dumbbell-shaped tensile samples with a gauge diameter of $10 \mathrm{~mm}$ and gauge length of $50 \mathrm{~mm}$ were machined from all of the cast plates, with the exception of the $7 \mathrm{~mm}$ plates, from which flat tensile samples were produced. The thickness, gauge width, and gauge length of the flat tensile samples were $5,7.5$, and $80 \mathrm{~mm}$, respectively. Tensile tests were performed using Zwick/Roell Z100 testing machine, following ISO 6892-1 [19]. The tensile test strain rate was set at $0.00025 \mathrm{~s}^{-1}$ up to fracture. Optical micrographs that were obtained from the metallographically polished samples were used for microstructure analysis. An image analysis software (Olympus Stream Motion) was used to measure the microstructural characteristics. Etching was performed using a 5\% Nital solution. Nodularity was evaluated following ASTM-E2567 [20]. Brinell hardness was measured according to the ISO 6506-1:2005 standard, using a $750 \mathrm{~kg}$ load and a $5 \mathrm{~mm}$ steel ball.

A Matlab script was developed and used to analyze the stress-strain curves obtained from the standard tensile test to measure the tensile properties [21]. Moreover, the Ludwigson equation (Eq. (1)) [22] was utilized to find the best fit for the experimental stress-strain curves and find the equation parameters.

$\sigma=K_{1} \varepsilon^{n_{1}}+\exp \left(K_{2}+n_{2} \varepsilon\right)$

where $\sigma$ is true stress $(\mathrm{MPa}), \varepsilon$ is true plastic strain, $n_{l}$ is strain-hardening exponent and $K_{l}$ is strength coefficient, $n_{2}$ and $K_{2}$ are two dimensionless parameters.

\section{Results and Discussion}

Figure 3 shows a typical micrograph obtained from the center of the cast plates. The graphite size increased when the plate thickness was increased up to $30 \mathrm{~mm}$, but stayed the same for plates thicker than $30 \mathrm{~mm}$. In contrary, no significant changes in graphite size could be observed with respect to the boron content. 


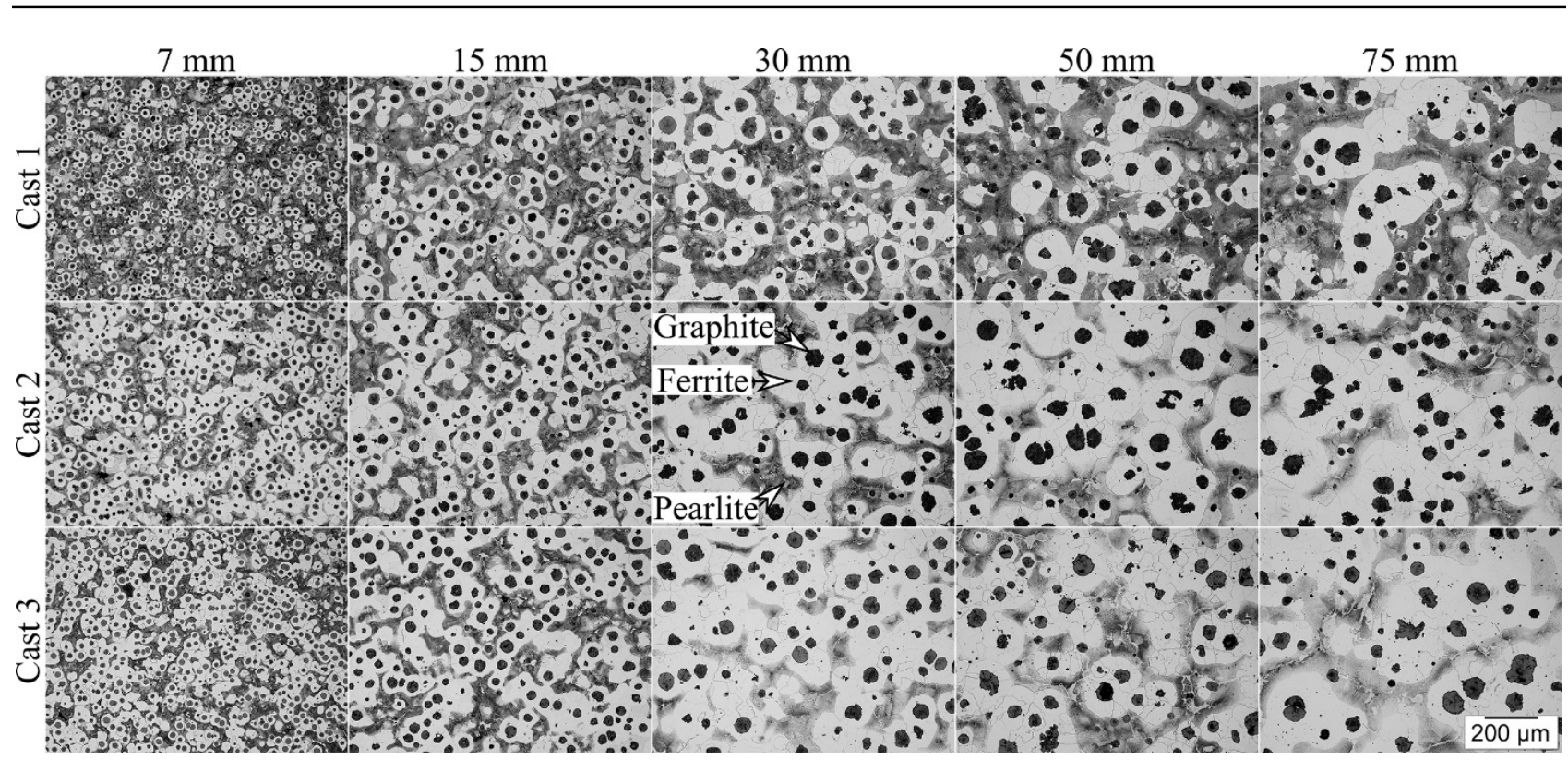

Figure 3. Representative micrographs for the cast plates, taken from the center of each cast plate. Graphite particles (dark gray), ferrite (white), and pearlite (lamellar light gray). The cast batches are given in the far-left of each row. The plate thicknesses are given in the top of each column.

The results of the microstructure analysis are presented in Figure 4. It is evident that the pearlite fraction was decreased in Cast 2 and 3 compared to Cast 1 (Figure 4(a)), which led to an increase in ferrite fraction in these batches (Figure 4(b)). On average, this reduction was $34 \pm 6 \%$ for each plate. Marginal changes in the pearlite fraction was observed with respect to the plate thickness in the three Cast batches. Comparing Cast 2 and 3, minor changes in pearlite fraction was measured, indicating that boron levels higher than $49 \mathrm{ppm}$ did not affect this fraction. This also indicates that boron is not likely to promote fully ferritic structures in ductile irons. Nevertheless, no conclusive trend was found in graphite fraction (\%), nodularity (\%), particle count (number of graphite particles per $\mathrm{mm}^{2}$ ), and nodule count (graphite particles with a shape factor of higher than 0.65 per $\mathrm{mm}^{2}$ ) with respect to the boron content (Figure 4(c)-(f)). 

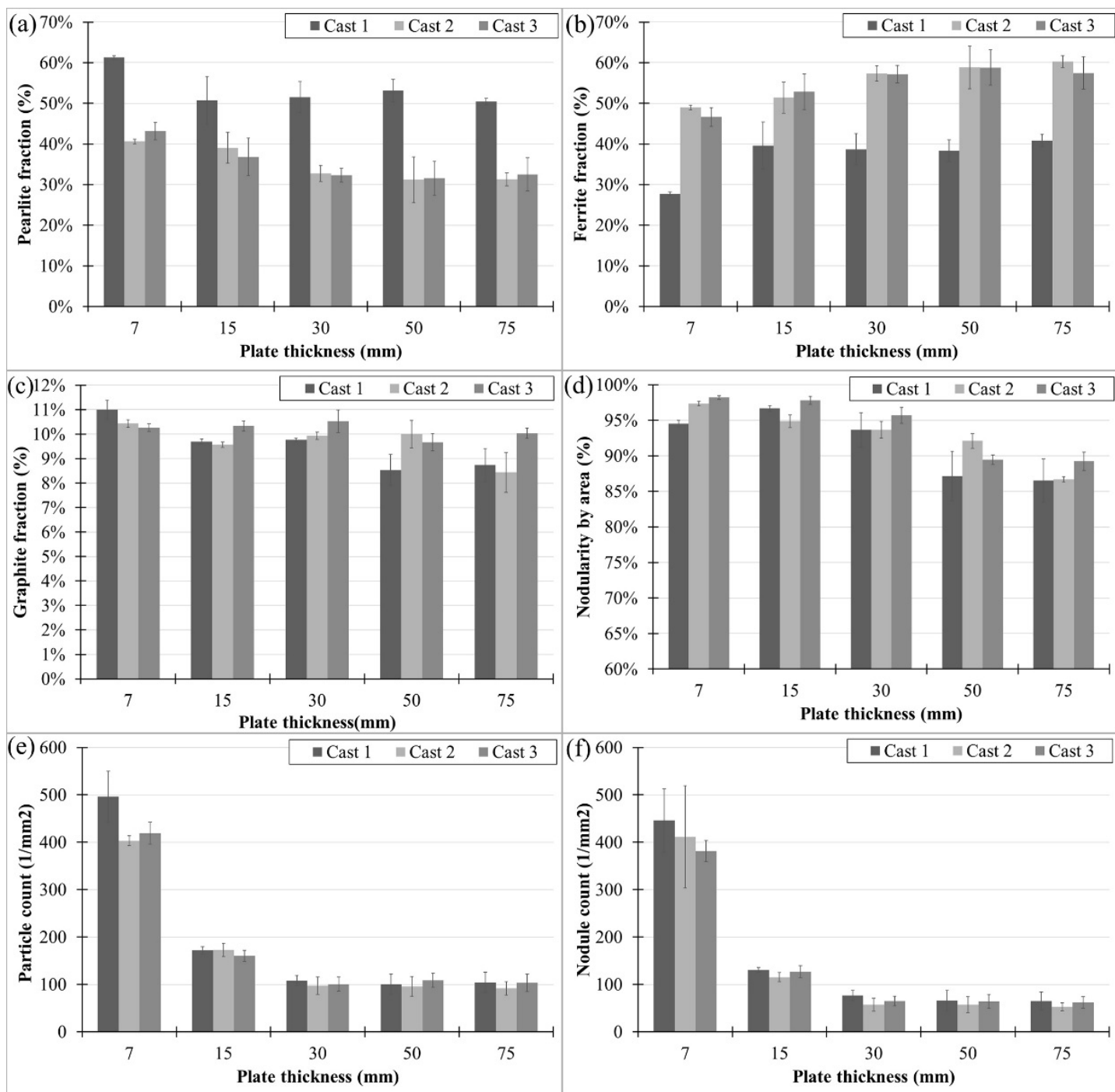

Figure 4. Microstructural characteristics of the Cast batches with respect to the plate thickness: (a) pearlite fraction (\%); (b) ferrite fraction (\%); (c) graphite fraction (\%); (d) nodularity by area (\%);

(e) graphite particle count $\left(1 / \mathrm{mm}^{2}\right)$; (f) nodule count $\left(1 / \mathrm{mm}^{2}\right)$.

The average of elastic modulus for all the cast plates was $169 \pm 2 \mathrm{GPa}$. On average, similar values of $0.2 \%$ offset yield $\left(\mathrm{Rp}_{0.2}\right)(\mathrm{MPa})$ and ultimate tensile strength $\left(\mathrm{R}_{\mathrm{m}}\right)(\mathrm{MPa})$ were obtained in the Cast 2 and Cast 3, see Figure 5(a) and (b). Compared to Cast 1, $R p_{0.2}$ and $R_{m}$ were decreased by an average of $11 \pm 1 \%$ and $18 \pm 2 \%$ in all of the cast plates, respectively. Hardness in Cast 2 was decreased compared to Cast 1 by an average of $16 \pm 1 \%$ in all the cast plates, see Figure 5(c). However, $11 \pm 2 \%$ hardness reduction was measured for cast 3 compared to cast 1 (i.e. $7 \pm 3 \%$ higher than cast 2). The reason for this difference could be due to the presence of the higher amount of boron carbide compounds in the third cast batch [23]. Lower elongation to fracture was obtained for the Cast 3 than the two other Cast batches, see Figure 5(d). The reason for this is not fully clear, and further investigation is required for ascertaining it. Note that low values of elongation to fracture in the $7 \mathrm{~mm}$ plates were due to the presence of shrinkage porosities.

Figure 6(a) shows typical tensile curves which were measured from the samples of the $30 \mathrm{~mm}$ plates. Figure 6(b)-(d) show the Ludwigson equation curve fittings to the actual tensile curves which are presented in Figure 6(a). As it can be seen, the modelled tensile curves perfectly fit to the experimental curves. Note that the curve fittings were done up to the ultimate tensile strength. 

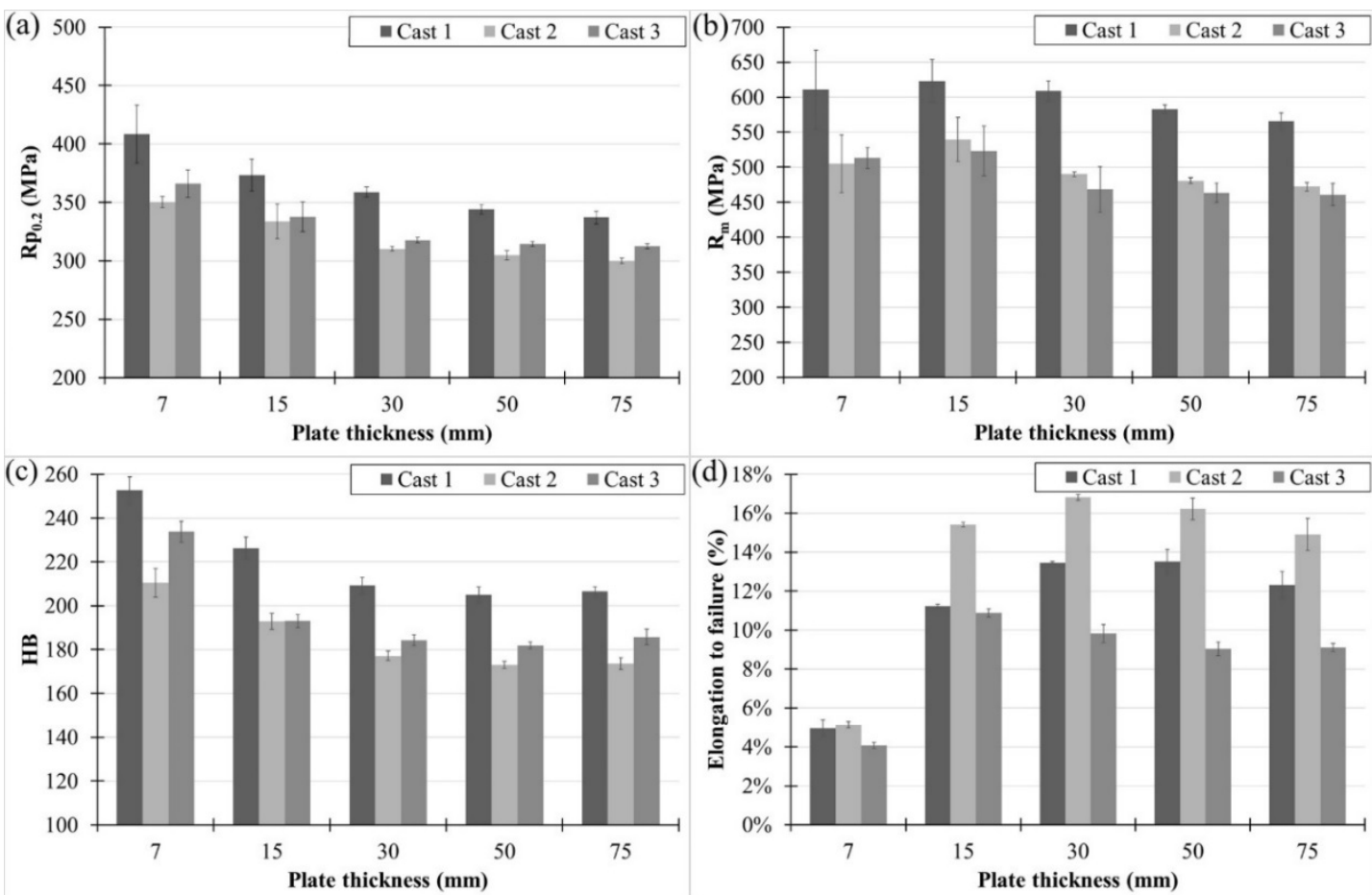

Figure 5. Tensile properties of the cast plates with respect to plate thickness:(a) $0.2 \%$ offset yield (MPa); (b) ultimate tensile strength $\left(\mathrm{R}_{\mathrm{m}}\right)(\mathrm{MPa})$; (c) Brinell hardness (HB); (d) elongation to fracture $(\%)$.

Figure 7 shows the Ludwigson equation parameters for the cast plates. Lower $n_{l}$ and $K_{l}$ values were obtained in Casts 2 and 3, indicating lower rates of work hardening with the addition of boron, which can be related to the lower work hardening of ferrite compared to pearlite. Marginal variation in $n_{2}$ values was obtained with respect to casting grade and plate thicknesses. Slightly higher values of $K_{2}$ in Cast 1 indicate a slightly higher degree of plastic deformation in the early stages of the tensile test in this cast.

\section{Conclusions}

Addition of 49 and $131 \mathrm{ppm}$ boron to ductile iron GJS-500-7 grade caused an average of $34 \pm 6 \%$ pearlite fraction reduction in all cast plates. No significant change was observed in the pearlite fraction by addition of boron from 49 to $131 \mathrm{ppm}$. Minor changes in the pearlite and ferrite fraction were obtained with respect to the plate thickness. Graphite fraction (\%), nodularity (\%), particle count $\left(1 / \mathrm{mm}^{2}\right)$, and nodule count $\left(1 / \mathrm{mm}^{2}\right)$ did not vary with respect to boron content.

Similar values of $\mathrm{Rp}_{0.2}$ and $\mathrm{R}_{\mathrm{m}}$ were obtained in Cast 2 and Cast 3, which were lower than Cast 1 in all the cast plates by an average of $11 \pm 1 \%$ and $18 \pm 2 \%$, respectively. Compared to Cast 1 , hardness was decreased by an average of $16 \pm 1 \%$ and $11 \pm 2 \%$ in Casts 2 and 3 , respectively.

Using the Ludwigson equation, a good fit could be obtained for the tensile curves. Addition of boron caused lower $n_{l}$ and $K_{l}$ values, which could be related to the lower work hardening of ferrite compared to pearlite. 
(a) 7

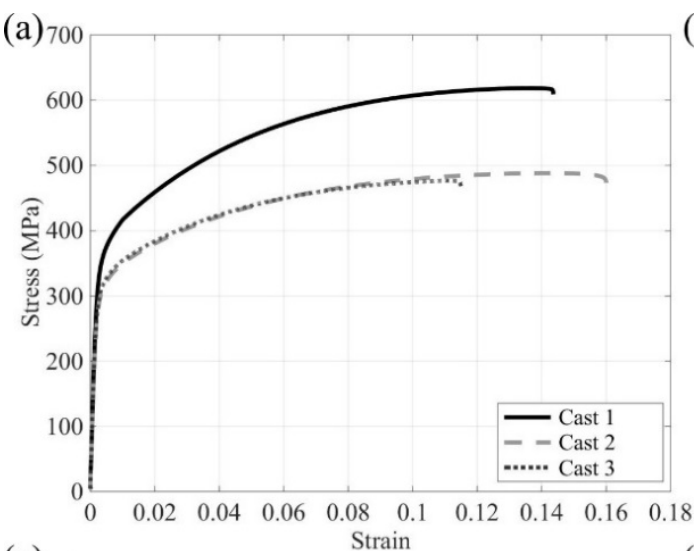

(c)

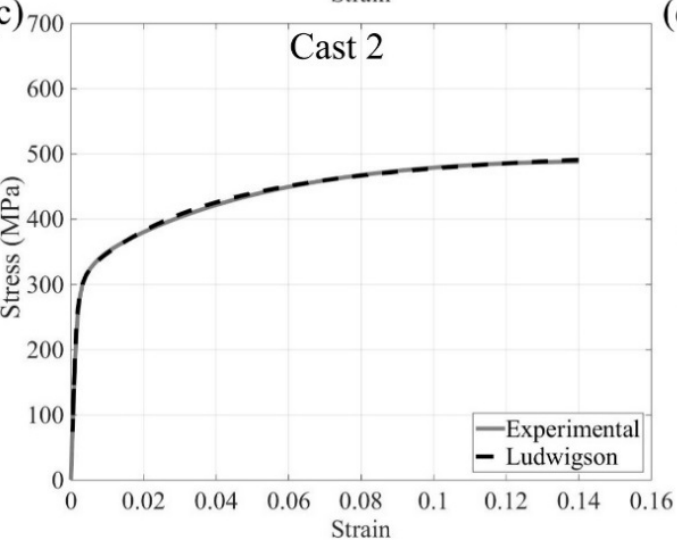

(b) 7

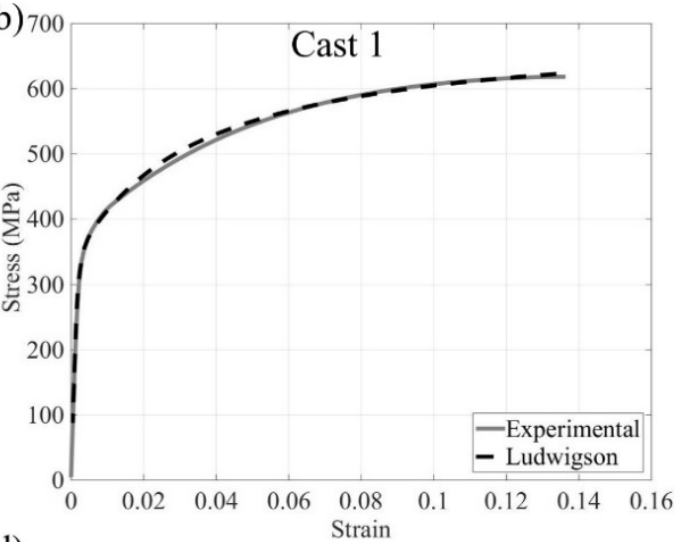

(d) 7

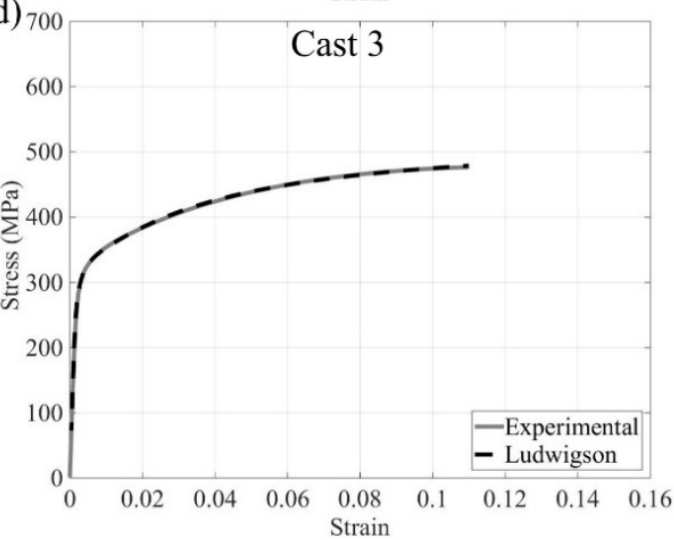

Figure 6. (a) Typical tensile curves of the $30 \mathrm{~mm}$ plate of the three Cast batches.

(b)-(d) Ludwigson curve fittings for the tensile curves presented in (a).
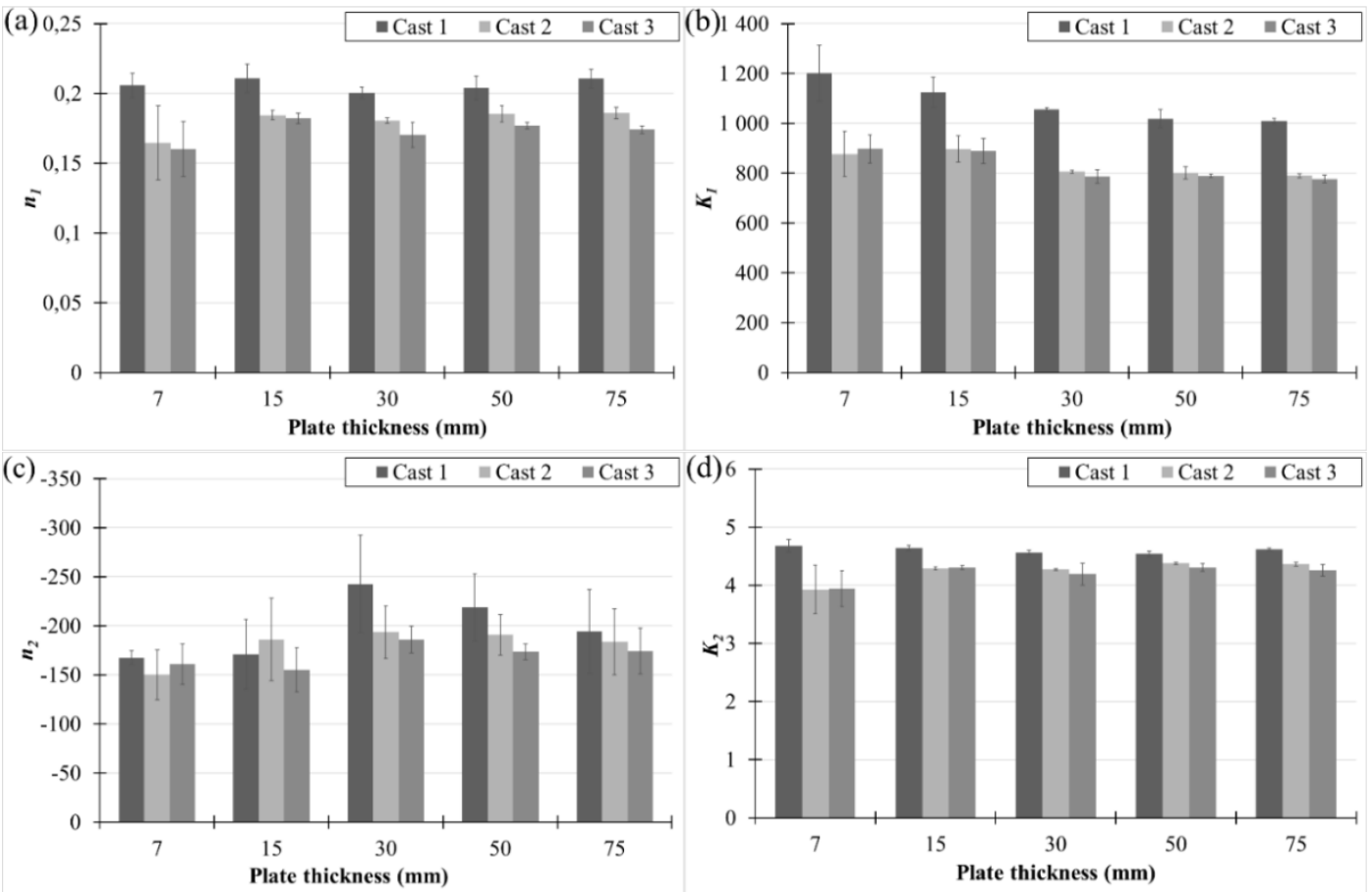

Figure 7. The Ludwigson equation parameters: (a) $n_{1}$, (b) $K_{1}$, (c) $n_{2}$, and (d) $K_{2}$.

\section{Acknowledgement}

The authors acknowledge the Swedish Knowledge Foundation for financial support under the CompCAST project (20100280). Nya Arvika Gjuteri AB and SKF Mekan AB are acknowledged for providing the cast material. 


\section{References}

[1] D.A. Mayton, Boron Related Hardness Problems, U.S. Ductile Iron Society (2003).

[2] R.B. Gundlach, Pearlitic Ductile Iron and the Conflict with Boron, Element Materials Technology, DIS Research Project No. 54 (2016).

[3] G. Melloy, P. Summon, P. Podgursky, Optimizing the boron effect, Metall Mater Trans B 4(10) (1973) 2279-2289.

[4] C. Meran, M. Yuksel, Usability of Boron as an Alloying Element in Gray Cast Iron Rollers and Its Effect to Abrasive Wear Behaviour, Adv Mat Res, Trans Tech Publ, 2012, pp. 331-336.

[5] R. Naro, J. Wallace, Y. Zhu, Elimination and Neutralization of Boron in Ductile Irons, DIS Project 39 (2004).

[6] K. Ankamma, Effect of Trace Elements (Boron and Lead) on the Properties of Gray Cast Iron, Journal of The Institution of Engineers (India): Series D 95(1) (2014) 19-26.

[7] Y.X. Li, Z.L. Liu, X. Chen, Development of boron white cast iron, Int J Cast Metal Res 21(1-4) (2008) 67-70.

[8] D.B. Narodnitskii, Effect of boron on the phase composition of high-chromium white cast irons, Met Sci Heat Treat + 21(8) (1979) 597-599.

[9] R. Gundlach, Effect of Boron in Ductile Iron, Hot Topics, The Ductile Iron Society (5) (2003).

[10] F.V. Guerra L, A. Bedolla-Jacuinde, I. Mejía, J. Zuno, C. Maldonado, Effects of boron addition and austempering time on microstructure, hardness and tensile properties of ductile irons, Mat Sci Eng A - Struct 648 (2015) 193-201.

[11] L. Jenkins, The Effect of boron in ductile iron, Ductile Iron News Strongsville, Ohio, USA (1) (2001).

[12] S. Mitra, D. Roy, T. Bhattacharyya, P.P. Chattopadhyay, Effect of boron on the manufacturing process and final properties of ductile iron pipes (DI pipes), Ironmak Steelmak (2017) 1-4.

[13] Y.-C. Peng, H.-J. Jin, J.-H. Liu, G.-L. Li, Effect of boron on the microstructure and mechanical properties of carbidic austempered ductile iron, Mat Sci Eng A - Struct 529 (2011) 321-325.

[14] Y. Zou, M. Ogawa, H. Nakae, Interaction of boron with copper and its influence on matrix of spheroidal graphite cast iron, Isij Int 52(3) (2012) 505-509.

[15] M. Gagné, C. Labrecque, You produce "soft" ductile iron casting? Check the boron content of the iron, Sorelmetal, Suggestions for ductile iron production (2006).

[16] K.A. Kasvayee, E. Ghassemali, I.L. Svensson, J. Olofsson, A.E.W. Jarfors, Characterization and modeling of the mechanical behavior of high silicon ductile iron, Mat Sci Eng A - Struct 708(Supplement C) (2017) 159-170.

[17] R. Ghasemi, L. Elmquist, H. Svensson, M. König, A. Jarfors, Mechanical properties of Solid Solution-Strengthened CGI, Int J Cast Metal Res (2016) 1-8.

[18] T. Skaland, A new method for chill and shrinkage control in ladle treated ductile iron, Foundry Trade Journal 178(3620) (2004) 396-400.

[19] E. ISO, 6892-1 Metallic materials Tensile testing Part 1: Method of test at room temperature, International Organization for Standardization (2009).

[20] ASTM Standard E2567-13a, 2013,"Standard Test Method for Determining Nodularity And Nodule Count In Ductile Iron", ASTM Internationals, West Conshohocken, PA, 2013, DOI:10.1520/E2567-13A, www.astm.org.

[21] I.L. Svensson, K. Salomonsson, Mathematical characterization of the tensile deformation curve of cast iron materials, $11^{\text {th }}$ International Symposium on the Science and Processing of Cast Iron SPCI11 2017 (2017).

[22] D. Ludwigson, Modified stress-strain relation for FCC metals and alloys, Metall Trans 2(10) (1971) 2825-2828.

[23] Z. Liu, Y. Li, X. Chen, K. Hu, Microstructure and mechanical properties of high boron white cast iron, Mat Sci Eng A - Struct 486(1) (2008) 112-116. 